Georgia State University

ScholarWorks @ Georgia State University

10-2011

\title{
Lesbian, Gay, and Bisexual Voters in the 2000 US Presidential Election
}

\author{
Gregory B. Lewis \\ Georgia State University, glewis@gsu.edu \\ Marc A. Rogers \\ Kenneth Sherrill \\ Hunter College, City University of New York, kenneth.sherrill@hunter.cuny.edu
}

Follow this and additional works at: https://scholarworks.gsu.edu/pmap_facpubs

Part of the Public Affairs, Public Policy and Public Administration Commons

\section{Recommended Citation}

Lewis, Gregory B.; Rogers, Marc A.; and Sherrill, Kenneth, "Lesbian, Gay, and Bisexual Voters in the 2000 US Presidential Election" (2011). PMAP Publications. 7.

https://scholarworks.gsu.edu/pmap_facpubs/7

This Article is brought to you for free and open access by the Department of Public Management and Policy at ScholarWorks@ Georgia State University. It has been accepted for inclusion in PMAP Publications by an authorized administrator of ScholarWorks @ Georgia State University. For more information, please contact scholarworks@gsu.edu. 


\title{
Lesbian, Gay, and Bisexual Voters \\ in the 2000 US Presidential Election
}

\begin{abstract}
Lesbians, gay men, and bisexuals (LGBs) in the United States are strikingly more likely to vote for Democratic presidential candidates than are heterosexuals. LGBs are one of the Democratic Party's most loyal voting blocs, despite the absence of one of the most important mechanisms for creating party identification: inter-generational transmission. We use the 2000 Presidential election to examine whether LGB voters overwhelmingly chose Al Gore because they viewed him as superior to George W. Bush on LGB-related policy issues or because of their greater overall liberalism and Democratic Party identification. We also examine the impact of socialization within the LGB community for generating political liberalism, Democratic Party identification, and interest in LGB policies. Using logit analysis on a 2000 Harris Interactive poll of 13,000 Americans, including 1,000 LGBs, we find that concern for LGB rights, policy liberalism, and party identification all played a role in the LGB vote. Analysis of the LGB subsample supports a model of political socialization within the LGB community leading to stronger interest in LGB rights, liberalism, Democratic party identification, and support for Gore.
\end{abstract}




\section{Lesbian, Gay, and Bisexual Voters}

\section{in the 2000 US Presidential Election}

Lesbian, gay, and bisexual (LGB $\left.{ }^{1}\right)$ voters in the United States have given twothirds or more of their votes to Democratic Presidential candidates at least since 1988 (Bailey, 2000; Egan, 2008; Egan, Edelman, \& Sherrill, 2008; Hertzog, 1996; Lewis, Rogers, \& Sherrill, 2003). This makes LGBs as consistent a Democratic voting bloc as Jews, Latinos, and the non-religious and nearly as consistent as African-Americans. A standard political socialization model of inter-generational transmission helps explain Jewish and African American loyalty to the Democratic Party, but LGBs' parents were not predominantly Democratic or liberal, and LGBs did not learn to see the world from an LGB perspective in their schools or childhood neighborhoods. Egan (2008, p. 127) sees the key potential explanations for LGBs' political distinctiveness as selection (the characteristics that cause people to adopt an LGB identity increase their likelihood of being liberal Democrats), embeddedness (LGBs are socialized to become liberal Democrats through involvement in the LGB community) and conversion (the process of choosing an LGB identity may be so life-altering that it causes major changes in political outlook).

We focus on the role of adult socialization in teaching LGBs to view politics in terms of what is good for LGBs. Using a 2000 Harris Interactive poll of 13,000 Americans, including more than 1,000 LGBs, we first confirm the political distinctiveness of LGBs. We then examine the impact of LGB-related policies on LGB Presidential 
votes. Finally, we look at the role of adult socialization, measured in terms of sexual identity, community involvement, out-ness, interest in LGB rights, and LGB activism.

Consistent with previous studies, we find that lesbians, gay men, and (to a lesser extent) bisexuals were decidedly more liberal, Democratic, and likely to vote for Al Gore than were heterosexuals. Controlling for demographic differences does little to explain the political differences, suggesting real limits on the importance of selection.

Ideological and partisan differences between LGBs and heterosexuals account for much of LGBs' strong preference for Gore, suggesting that a conversion experience might be responsible, but LGBs were still strikingly more likely than demographically comparable heterosexuals of the same ideology and party identification to vote for Gore. Consistent with a model of voting based on LGB group interests, attention to LGB rights largely explains the remaining difference: LGBs who paid no attention to LGB rights were indistinguishable from comparable heterosexuals in their Presidential preference, but virtually all of those who paid a lot of attention to LGB rights voted for Gore. Within the LGB sample, sexual identity, social involvement, being out, and concern for LGB rights all interacted in affecting liberalism and Presidential preference in 2000, consistent with a model of adult socialization.

\section{Explaining LGB Political Distinctiveness}

Campbell, Converse, Miller and Stokes (1964) introduced the concept of distinctive political groupings: Jewish, but not Catholic, voters were distinctively liberal and Democratic, for example, because differences in income, education, urbanization,

\footnotetext{
${ }^{1}$ Although the acronym is typically LGBT, samples of transgendered Americans have generally been too small to make meaningful statements about their political beliefs and behaviors. As we note below, even
} 
and union membership could account for Catholic-Protestant, but not for JewishProtestant, vote differences. Distinctive political groupings typically form in childhood, with parents (usually reinforced by schools and neighborhoods) conveying their identities and values to children (Berelson, Lazarsfeld, \& McPhee, 1986; Campbell, et al., 1964; Greenstein, 1965; Jennings \& Niemi, 1968). Children generally identify with the same political party as their parents by the fourth grade; by eighth grade, they explain that their party is good for people like them and their families (Greenstein, 1965). Party loyalty is reasonably stable over the life cycle (Green, Palmquist, \& Schickler, 2004), as later contacts often reinforce people's perception that their party is good for people like them.

Children who will later experience same-sex attraction should be randomly distributed in the population, meaning that they grow up in the same neighborhoods, attend the same schools, and receive the same political socialization as heterosexuals. In the absence of forces that lead them to question that socialization more than heterosexuals, both groups should have similar ideologies and party identifications. The repeated finding that self-identified LGBs are dramatically more liberal and Democratic than others (Bailey, 2000; Edelman, 1993; Egan, et al., 2008; Herek, Norton, Allen, \& Sims, 2010; Hertzog, 1996) therefore requires an alternative explanation of how so many choose new partisan attachments and take on ideologies far more liberal than their parents.

Egan (2008) summarizes the alternative explanations as (1) essentialism (homosexuals have distinctive values, whether they adopt an LGB identity or not); (2) 
selection (the characteristics that cause people with same-sex attractions to be more likely to adopt an LGB identity also make them more liberal and thus more likely to identify with the Democratic Party); (3) embeddedness (LGBs receive a new political socialization through membership in the LGB community, which is distinctively liberal and Democratic); and (4) conversion (the process of choosing an LGB identity forces many to re-think their values and sympathize more with other "outsider" and marginalized groups).

The logic for essentialism is not clear, and a true test of it would require a random sample of people who experience same-sex attraction or engage in same-sex sex, a near-impossibility due to widespread condemnation of homosexuality²: A nonrandom portion of those who feel same-sex attraction act on it, a nonrandom portion of them acknowledge having had same-sex sex, and a nonrandom portion of those who acknowledge having had same-sex sex identify as LGB. Under-reporting has traditionally been substantial: the percentage of General Social Survey (GSS) respondents who reported having had same-sex partners doubled between 1991 and 2000 (Lewis \& Rogers, 2002) and the percentage who identified as LGB on exit polls rose by a similar amount (Bailey, 2000). AIDS researchers discovered such a divide between homosexual practice and identity that they coined the term "men who have sex with men" (MSM) to describe the group most relevant to their research. A random

\footnotetext{
${ }^{2}$ Polling data for 2000 indicate that $46 \%$ of Americans believed "homosexuality is a sin" (PSRA/Newsweek), 51\% agreed that "homosexual behavior is morally wrong" (Kaiser Family Foundation), and $54 \%$ said sexual relations between two adults of the same sex ... is always wrong" (General Social Survey). Public opinion has become a bit more favorable, but 2010 polling data still find $43 \%$ calling "gay or lesbian relations ... morally wrong" (Gallup), $48 \%$ saying "homosexual relationships between consenting adults is morally wrong" (CNN), and $49 \%$ believing "homosexual behavior is ... morally wrong" (Pew; only 9\% said it was "morally acceptable" and 35\% said it was "not a moral issue").
} 
national sample found that $50 \%$ more men acknowledged having had sex with a man in the previous five years than identified as gay (Laumann, Gagnon, Michael, \& Michaels, 1994). In a large random sample of New York City residents, men who reported having had sex only with men in the prior year were much many times more likely to identify as straight than as gay (Pathela et al., 2006).

Evidence for the selection hypothesis is clearer. Self-identified LGBs tend to be younger, better educated, less affluent, more urban, less Southern or Midwestern, and less likely to identify with an organized religion than other respondents (Bailey, 2000; Egan, et al., 2008; Herek, et al., 2010; Hertzog, 1996; Sherrill, 1996). All these characteristics predict liberalism, suggesting that LGB liberalism owes much to these other characteristics. These surveys could also overstate LGB liberalism, however, if liberal and Democratic LGBs feel safer in revealing their sexual orientation than conservative and Republican LGBs. That would suggests that the bias would decrease as under-reporting drops, however, and Lewis and Rogers (2002) found that the liberalism and Democratic party identification of GSS respondents acknowledging same-sex sex partners remained stable even as their numbers doubled between 1991 and 2000.

Egan (2008) sees the selection problem not just in willingness to report having had same-sex sex but in the acceptance of one's sexuality that goes along with adopting an LGB identity. He notes that in the survey of New Yorkers (Pathela, et al., 2006), being white, better educated, and higher income all increased that odds that MSM identified as gay or bisexual. Re-analyzing the GSS data, Egan (2008) finds that, 
among respondents who reported same-sex sex partners, those who were raised by

college-educated mothers in non-fundamentalist households outside the South were

much more likely to say that homosexual relations were "not wrong at all" (his proxy for

an LGB identity). ${ }^{3}$ Controlling for factors set by adolescence (race, sex, and

characteristics of the families in which they were raised) decreased the LGB-

heterosexual difference in liberalism by one-fifth. ${ }^{4}$

The embeddedness hypothesis argues that incorporation into the LGB

community leads to a new political socialization, perhaps because LGBs come to view

other LGBs as their primary reference group and view American politics through the

lens of LGB interests. According to Conover (1984, p. 783), when one feels a

psychological attachment to a group, its interests "may actually become even more

relevant than self-interests in ... political perception and evaluation." This has been the

\footnotetext{
${ }^{3}$ Egan et al. (2008) also found that their random national sample of self-identified LGBs was much more likely than the general population to have been raised by college-educated mothers in non-fundamentalist households outside the South. The 2008 and 2010 GSS do include a question about sexual orientation. Among respondents who had had at least one same-sex sex partner in the previous five years, $3 \%$ of those who identified as gay or lesbian, $10 \%$ of those who said they were bisexual, and $50 \%$ of those who said they were heterosexual said that sexual relations between two adults of the same sex were at least "sometimes wrong." In these two surveys, being raised by a college-educated non-fundamentalist mother outside the South did not significantly impact either identifying as LGB or saying that homosexual sex was "not wrong at all."

${ }^{4}$ In contrast, he found that people with same-sex sex partners who did not adopt an LGB identity were no more liberal than heterosexuals (arguing against the essentialist hypothesis). Our reanalysis of 19912000 GSS data, however, indicated that believing homosexual sex was "not wrong at all" was as strong a predictor of liberalism for those who did not as for those who did report same-sex sex partners; with that belief held constant, respondents with same-sex sex partners were 14 to 17 percentage points more likely to be liberal than comparable respondents without same-sex sex partners. In the party identification model, on the other hand, an interaction term between having same-sex sex partners and thinking homosexual sex is "not wrong at all" approached statistical significance $(p=.15)$; respondents with samesex sex partners who said "not wrong at all" were significantly more Democratic than comparable heterosexuals who said "not wrong at all", but those who did not say "not wrong at all" were not significantly more Democratic than comparable heterosexuals - though both point estimates were about 6 percentage points.
} 
implicit assumption of much work on the political behavior of LGBs (Bailey, 1999; Hertzog, 1996; Sherrill, 1996).

The emergence of homosexuality and gay rights as explicit political issues over the past three decades and a clear polarization of party elites over LGB rights in employment (including in the military) and family recognition (civil unions, marriage, and adoption) made LGB identity politically salient by 2000 . In 1996 , one-third of the Democrats in both houses of Congress, but only one (openly gay) Republican, had voted against the Defense of Marriage Act; and $87 \%$ of Democratic but only $13 \%$ of Republican Senators had voted for the Employment Non-Discrimination Act (Lewis \& Edelson, 2000). In 2000, the Democratic Party platform stated: "We support continued efforts, like the Employment Non-Discrimination Act, to end workplace discrimination against gay men and lesbians. We support the full inclusion of gay and lesbian families in the life of the nation. This would include an equitable alignment of benefits."("Democratic Platform 2000," 2000). In contrast, the Republican Party platform declared, "We support the traditional definition of 'marriage' as the legal union of one man and one woman, and we believe that federal judges and bureaucrats should not force states to recognize other living arrangements as marriages. ... [W]e do not believe sexual preference should be given special legal protection or standing in law." Further, it noted, "We affirm that homosexuality is incompatible with military service" ("2000 Republican Platform," 2008).

One means of testing adult socialization is assessing the impact of LGB-specific issues on Presidential votes. Schaffner and Senic (2006) tested the effects of concern 
for LGB rights and for more tangible benefits on LGB voting in the 2000 election. Using a Princeton Survey Research Associates (PSRA) survey of 361 LGBs randomly selected from lists of people associated with LGB interests and activities, they found that desire for domestic partner benefits mattered more than interest in rights (nondiscrimination laws and same-sex marriage) in pushing LGBs toward the Democratic Party and a pro-Gore vote in 2000 . They took for granted, however, that LGB interests mattered more than general policy liberalism (their data contained no measure of it). In contrast, using the 1991-2000 GSS, Lewis and Rogers (2002) found strong Presidential vote differences in 1988-96 between those who had and had not had same-sex sex partners in the past five years, even after controlling for a variety of demographic variables. Once they controlled ideology and party identification, however, that difference dropped to statistical insignificance - except in 1992, when Clinton appeared to pick up an extra 10 percentage points of the LGB vote that could not be explained by party, ideology, or non-LGB policy positions. Egan (2008) also found little evidence that involvement in the LGB community makes LGBs more liberal or Democratic: although heterosexuals who live in precincts with more LGB neighbors are far more liberal and Democratic than those who live in nearly exclusively heterosexual precincts, LGBs in gay ghettos are no more liberal or Democratic than those who live in nearisolation. Further, he argues, LGBs are as politically distinct from similar heterosexuals when they emerge from the closet as when they have lived with an LGB identity for decades: LGBs tend to be liberals at the moment they come out, and their liberalism does not increase with greater contact with other LGBs (either by living in gayer 
neighborhoods or having interacted with LGBs over a longer period of time).

This pushes Egan (2008) to the conversion hypothesis. Adopting an LGB identity in a society where major religious and political authorities condemn homosexuality as morally wrong or sick forces many to question those authorities, leading to a more general ideological transformation. In coming out, many LGBs realize that the values they were raised with contradict the reality of who they are. LGBs are far more likely than heterosexuals to have abandoned the religions of their childhood (Egan, et al., 2008; Lewis \& Rogers, 2002) and to have rejected their parents' Republican party identification (Egan, et al., 2008). As Egan (2008, pp. 14, 15) puts it, adopting 'a 'stigmatized' or 'outsider' status (Becker, 1963; Goffman, 1963) ... [may] lead gay people to sympathize with those who belong to other marginalized groups and thus support politicians and policies that they believe help these groups" and "give LGBs an incentive to alter their political views in order to reduce the incongruousness between their newfound identity and the American national political environment." A feeling of shared oppression could make LGB Americans more skeptical of the status quo, inducing a broader social liberalism and at least some fellow feeling with other minorities. Certainly, LGBs are far more liberal than comparably educated heterosexuals of the same age on a wide array of issues unrelated to sexual identity (for example, the death penalty, legalization of marijuana, defense and domestic spending, and the war in Iraq (Bailey, 2000; Edelman, 1993; Egan, 2008; Egan, et al., 2008; Hertzog, 1996; Lewis \& Rogers, 2002; Sherrill, 1996)). In sum, LGBs' marked preference for Democratic Presidential candidates might 
arise because (1) the same characteristics that makes people more willing to adopt an LGB identity also makes them more likely to be liberal Democrats; (2) adult socialization within the LGB community increases liberalism, Democratic Party identification, and willingness to base political behavior on the interests of LGBs; and/or (3) the coming out process may lead LGBs to question authority and the status of out-groups, increasing their policy liberalism. Testing the relative validity of these theories has been hampered by the shortage of good data on the political views or community involvement of random samples of self-identified LGBs. Previous studies make creative use of limited data sets.

We use a large, arguably random sample of heterosexuals and LGBs with measures of liberalism, party identification, and Presidential vote for all respondents and detailed measures of LGB community involvement and interest in LGB-related policies for the LGB sub-sample. Our data set does not allow us to test whether background characteristics that Egan (2008) finds increase willingness to identify as LGB can account for LGBs political attitudes or behaviors. Nor does it allow us to test whether LGB identity or socialization makes one more liberal on non-LGB issues. We try to control for those perspectives as well as the data allow.

\section{Data}


In 2000, the Gill Foundation funded a Harris Interactive poll to study LGBT ${ }^{5}$ voters. Harris polled 13,000 respondents from the Harris Poll Online "database of 7.2 million cooperative respondents who have opted in to receive invitations to take part in online surveys" (Gill Foundation, 2001, p. 83). The survey was conducted online less than one month after the 2000 election (November 30 to December 5). All respondents answered a series of general questions, and the 1146 LGB respondents then answered a series of LGB-specific questions (Gill Foundation, 2001).

Harris applies sophisticated weighting to compensate for potential bias due to unequal access to the Internet. It "uses several demographic variables (for example, sex, age, education, race and ethnicity) as well as a variable representing the propensity of an individual respondent to be online, a composite of several factors, to generalize survey results to the general population" (Gill Foundation, 2001, p. 85). Propensity weighting is controversial within the polling community, but the 2000 Harris pre-election poll stacked up well against traditional telephone polls (it predicted "a statistical dead heat, $47.4 \%$ for Gore to $47.2 \%$ for Bush," and predicted the vote split within 2 percentage points in 36 of 38 states (RFL Communications, 2000)). After weighting (which includes balancing to the population and propensity weighting), both the Harris sample and the Voter News Service exit polls indicated that 71 percent of LGB voters chose Gore in 2000.

5 The Harris data include 19 transgender respondents, who split their vote fairly evenly between Bush and Gore. As this number was too small to allow meaningful analysis, we dropped these 19 cases (plus all other respondents who did not identify as heterosexual, lesbian, gay, or bisexual) to simplify some of the later analyses. Those who were not sure how to categorize themselves, or refused to do so, were somewhat more likely than comparable heterosexuals, but somewhat less likely than comparable LGBs, 
For the full sample, we use three dependent variables: Liberalism (coded from $0=$ conservative to $2=$ liberal), Democratic party identification (coded $0=$ Republican to 2=Democrat), and Gore Vote (coded 1 for those who voted for Al Gore, 0 for those who voted for George W. Bush, and missing for others). For the LGB sample, we created five additional dependent variables. First, we measured sexual identity with a dummy variable Gay/Lesbian coded 1 for the 52 percent who labeled themselves lesbian or gay rather than bisexual ${ }^{6}$. Second, we measured Social Involvement as an ordinal-level variable that is coded 3 for the 14 percent who said they were "very ... socially ... active in the gay and lesbian community," 2 for the 38 percent who were "somewhat active," and 1 for the 47 percent who were "not active at all."

Third, we created the interval-level Openness as a measure of how open respondents were about their sexual orientation with their parents, brothers and sisters, other relatives, other adults in their households, close friends, co-workers or colleagues, and acquaintances or casual friends. For each of these seven groups, we coded respondents as 0 if they said "not open at all," 1 if they said "somewhat open" or "not applicable,"7 and 2 if they said "very open." Openness is the mean of the seven items $($ Cronbach's alpha $=.89): 13$ percent said they were very open in all these situations, 54 percent gave more "very open" than "not open at all" responses, and the mean of 1.1

to vote for Gore - but the Harris screening structure eliminated them from several questions that would have made comparison to LGBs easier.

${ }^{6}$ Egan et al. (2008) also found that half their sample of LGBs were bisexuals. Both studies also found that women were far more likely than men to identify as bisexual: $69 \%$ of the women and $37 \%$ of the men in our sample were bisexual (compared to $65 \%$ and $32 \%$ in Egan et al. (2008)).

7 We interpreted "not applicable" to mean that respondents did not have anyone who met that criterion in their lives. Thus, $18 \%$ indicated that their openness to "brothers or sisters" and to "other adults in the 
shows that most respondents were at least "somewhat open" in most situations. Openness was much higher for gay men and lesbians (1.4) than for bisexuals (0.8).

Fourth, the interval-level Attention to LGB Rights measures "how much attention you pay to the following gay and lesbian public policy issues": hate crimes legislation, gay adoptions, gays in the military, legal recognition of same-sex unions, and laws prohibiting anti-gay workplace discrimination. Responses were on a four-point scale (1="none at all," 2="a little," 3="some," and 4="a lot"). Substantial majorities said they paid at least some attention to all issues. The five items all loaded heavily on a single factor (.80 or higher, using principal components factor analysis), and a simple sum of the five items was highly reliable (Cronbach's alpha $=.90$ ). The mean was 3.00 ("some"), but much higher for lesbians and gay men (3.4) than for bisexuals (2.6). These issues are more rights than benefits, which Schaffner and Senic (2006) concluded had less impact on the LGB vote in 2000 . The high reliability of the five items suggests no reason to divide them into different groups.

Fifth, we calculate LGB Activism as the mean of five items on how important (on a scale from 1="not at all" to 4="very") respondents considered it to take part in "talking to others about public policy issues that affect the gay and lesbian community, reaching out to gays and lesbians who are not open about their sexual orientation, voting for candidates who support gay and lesbian issues, contributing time or money to candidates who support gay and lesbian issues, and attending political activities (e.g., rallies, marches, demonstrations) in support of gay and lesbian issues" (Cronbach's

household" was not applicable, but only $1 \%$ said that for "close friends." Scoring "not applicable" as 2 may bias scores toward the mean. 
alpha $=.90$ ). The mean was 3.0 ("somewhat important") for lesbians and gay men and 2.2 ("not very important”) for bisexuals.

Our independent variables are a set of dummy variables distinguishing between men and women (the reference group); between African-Americans, Latinos/Hispanics, Asian-Americans, other/mixed race, and non-Hispanic whites (the reference group); and between Catholics, Jews, members of other religions, those without religious affiliations, and Protestants (the reference group). We measure both age and education in years and years-squared (to allow curvilinear relationships) and household income in hundreds of thousands of USD (this increases the size of the coefficient but does not change its meaning), adding a dummy variable coded 1 for those who refused to state their income.

We also included the dummy variables Gay man, Lesbian, Bisexual man, and Bisexual woman in analysis on the full sample, which includes heterosexuals. That means that the Male coefficient shows political differences between male and female heterosexuals. These sexual identity coefficients distinguish between LGBs and heterosexuals of the same sex. In the LGB-only analyses, we drop Bisexual man and Bisexual woman, so the Male coefficient distinguishes between male and female bisexuals, and the Gay man and Lesbian coefficients distinguish these groups from bisexuals of the same sex.

\section{Method}

We begin by showing that lesbians, gay men, and bisexual men and women were all much more likely than heterosexual men and women to be liberals, Democrats, 
and Gore supporters. We start with simple comparisons among the various sexual identities. (We weight all analyses.) To provide a weak test of the selection hypothesis, we then run binary or ordered logit models that control for race, sex, education, age, income, and religion. Changes in LGB-heterosexual political differences due to introducing the control variables should indicate upper limits on the effects of selection, as education, religion, and income may all reflect rather than cause LGB distinctiveness. Because logit coefficients can translate into different probability differences at each prior probability, we set the heterosexual probabilities to those in Table 1 and calculate percentage differences from those prior probabilities.

As a weak test of conversion, we then add political ideology and party identification to the model for Presidential vote to see whether LGB-heterosexual differences shrink substantially. Although many data sets measure ideology and party identification on five- or seven-point scales, this survey did not allow respondents to call themselves "very liberal" or "strong Democrats" or allow independents to lean to one party or the other. The crudeness of these measures probably understates the effect of ideology and party identification in explaining LGB-heterosexual vote differences. Further, although we know that LGBs are far more liberal than heterosexuals on a variety of issues apparently unrelated to sexual orientation, the survey did not ask any questions about non-LGB policy issues, potentially under-stating the importance of broad policy liberalism in explaining the 2000 vote.

To see to what extent interest in LGB rights pushed LGBs to support Gore, we then add Attention to LGB Rights to the Gore Vote model. We set this variable to its 
minimum value for non-LGB respondents, as they were not asked the questions. If LGB-specific policy interests played a major role in the LGB vote for Gore, all the LGB coefficients will shrink with this new variable in the model.

We next look at socialization of LGBs within the LGB community. Activists generally call on LGBs to embrace an LGB identity, to come out to friends and family, to support LGB rights, and to work to advance LGB policy interests. We hypothesize that: (1) Lesbians and gay men have greater social involvement in the gay and lesbian community than bisexuals; (2) Social involvement socializes LGBs into both more openness about their sexuality and greater interest in LGB rights; and (3) Social involvement, openness, and attention to LGB rights increase activism on behalf of LGB policy interests. In an analysis restricted to the LGB sample, we run a logit model for sexual identity, an ordered logit model for social involvement, and regression models for openness, attention, and activism (these latter three variables are means of 5 to 7 items). We then run ordered logit and logit models for ideology, party identification, and Gore vote on the LGB sample, adding all these variables except LGB activism. If the embeddedness/political socialization hypothesis holds, social involvement, openness, and interest in LGB policy issues should all increase liberalism, Democratic party identification, and support for Gore.

\section{Findings}

\section{LGB-Heterosexual Comparisons}

As others have shown, LGBs are distinctively liberal and Democratic (Table 1). The distinctiveness is much stronger for lesbians and gay men (who are three times as 
likely as heterosexuals of the same sex to be liberal and only one-fifth as likely to be conservative) than for bisexuals (who are about 50 percent more likely than heterosexuals of the same sex to be liberal). For example, $50.1 \%$ of gay men and $56.3 \%$ of lesbians describe themselves as liberals, compared to $21.5 \%$ and $33.0 \%$ of bisexual men and women and only $14.9 \%$ and $19.4 \%$ of heterosexual men and women. Substantial majorities of lesbians and gay men are Democrats, about twice the rate for heterosexuals of the same sex. Support for Al Gore was overwhelming among lesbians (84.5\%), gay men (78.1\%), and bisexual women (70.5\%) and strong among bisexual men (57.3\%; another $11.1 \%$ supported Ralph Nader, his highest level of support ${ }^{8}$ ).

As others have shown, demographic differences explain little of the LGBheterosexual difference in ideology, party identification, and Presidential vote. In Table 2, the gay and lesbian coefficients are always highly significant (and the bisexual coefficients usually are), even after controlling for race/ethnicity, age, education, income, and religion. Gay men and lesbians remain as distinctively liberal and Democratic as other groups traditionally associated with the Democratic Party. Their coefficients are about the same size as the Jewish coefficients, stronger than the African American coefficient on liberalism but weaker on party identification and vote, somewhat stronger than the non-religious coefficients, and far larger than the Latino and Catholic coefficients.

Demographic differences do a poor job of explaining LGB political distinctiveness. The raw differences in Table 1 are only a little larger than the controlled

\footnotetext{
${ }^{8}$ Herek et al. (2010) also found that bisexual men were more likely than lesbians or gay men to support Nader in 2004.
} 
differences implied by Table 2, setting the male and female heterosexual percentages to their values in Table 1. For example, gay men are 35.2 percentage points more likely than heterosexual men to be liberals (50.1 versus 14.9 in Table 1 ); if we set a heterosexual man's probability of being liberal to 14.9 percent, the ordered logit coefficient on Gay man translates into a nearly identical 34.5 percentage point difference between gay and heterosexual men of the same race, religion, age, education, and income. Lesbians are 36.9 points more likely than heterosexual women, and 31.5 points more likely than demographically comparable heterosexual women, to be liberals. Controlling for demographics expands the bisexual-heterosexual difference for men (from 6.6 to 11.9 percentage points) but eliminates it for women (shrinking it from 13.6 percentage points to statistical insignificance). Controlling for demographic differences also narrows the gay-straight difference in Democratic party identification slightly for men (from 29.9 to 28.5 points) but widens it slightly for women (from 29.3 to 31.0 points). The gay-heterosexual difference in support for Gore barely changes with demographic controls for either men (from 43.2 to 44.1 points) or women (from 34.5 to 33.6 points). In short, these simple demographic differences cannot explain LGBheterosexual ideology, party, and vote differences.

Ideological and partisan differences are more helpful in explaining LGBs' strong preference for Gore. Adding them to the Gore Vote // model shrinks the gayheterosexual difference by 11 percentage points for $\operatorname{men}^{9}$ and by 13 points for women.

\footnotetext{
9 The Gay man coefficient drops from 2.01 to 1.39 . We translate that coefficient into a probability difference, assuming that the heterosexual man had a $37.9 \%$ probability of voting for Gore. This is the Gore percentage of the heterosexual male vote in Table 2, dropping all votes for anyone other than Bush and Gore. $($ That is, $37.9 \%=(35.4 /(35.4+58.0)) * 100$.
} 
Controlling for ideology and party identification has a much weaker effect for bisexual men, and it slightly widens the difference between bisexual and heterosexual women. All differences remain substantial even between demographically and ideologically similar LGBs and heterosexuals of the same party identification, however. Gay men were 33 percentage points and lesbians and bisexuals were 20 percentage points more likely to vote for Gore than demographically comparable heterosexuals of the same sex who also had the same ideology and party identification.

Adding Attention to LGB Rights (with all heterosexuals coded at the minimum value) to the Gore Vote III model shrinks all the sexual identity coefficients to statistical insignificance, both individually and jointly. Lesbians, gay men, and bisexuals who paid no attention to LGB rights were no more likely than comparable heterosexuals to vote for Gore. Holding the other variables at their means, however, LGBs who paid a lot of attention to those issues were 39 percentage points more likely than heterosexuals to vote for Gore.

This is consistent with the finding of Schaffner and Senic (2006) that LGB interests played an important role in LGBs' strong preference for Gore in 2000. Contrary to their findings, however, LGB rights mattered, though our survey did not include measures of more tangible economic benefits. The high reliability of our measure, however, casts doubt on whether interest in domestic partner benefits measures something meaningfully different than interest in non-discrimination laws or same-sex marriage. Our model also corrects for LGBs' greater liberalism (which the PSRA survey did not ask about) - providing a stronger test of conversion vs. 
embeddedness - and for sex, race/ethnicity, and age (which their smaller sample size precluded) - providing stronger protection against spurious relationships. The Harris survey also uses a more plausibly random sample of LGBs, based on sampling from the general population rather than from lists of people associated with LGB interests and activities.

\section{Political Socialization in the LGB Community?}

Gay men and lesbians differed from bisexuals on a variety of dimensions beyond their politics (Table 3). In Model 1, the dependent variable is coded 1 for those who identify as gay or lesbian and 0 for those who identify as bisexual; thus, positive coefficients indicate characteristics that increase one's probability of identifying as gay/lesbian. Because logit coefficients have little intuitive meaning, we translate significant coefficients into probability differences, holding the other variables at their means, and discuss those probability differences rather than the coefficients. Holding the other variables at their means, men were 30 percentage points more likely than women, and blacks were 27 points less likely than non-Hispanic whites, to identify as gay/lesbian rather than bisexual. Nonreligious LGBs were about 16 points more likely than Protestant LGBs, and college graduates were 16 points more likely than high school graduates, to identify as gay/lesbian. .

Sexual identity strongly influenced social involvement in the gay and lesbian community. According to Model 2, bisexual men and women with the mean characteristics of the data set had 88 and 66 percent probabilities of not being socially 
active at all in the community. ${ }^{10}$ Lesbians and gay men with the same characteristics had only 31 and 26 percent probabilities of being that isolated from other LGBs.

Beyond identity, only age predicted level of social involvement: with each 10 years of age, the probability of no active involvement rose by about 7 percentage points. In a separate logit analysis (not shown), sexual identity also had a major impact on having at least one gay or lesbian friend, especially for women. Holding the other variables at their means, bisexual women had a $53 \%$ chance of having an LGB friend, compared to $71 \%$ for bisexual men, $82 \%$ for gay men, and $88 \%$ for lesbians.

Both social involvement in the community and gay/lesbian identity predicted greater openness about one's sexuality, more interest in LGB rights, and higher levels of LGB political activism. A one-point rise on the three-point social involvement scale raised openness by .27 point on a three-point scale (Model 3) and increased attention to LGB rights by .45 point on a four-point scale (Model 4). Bisexual men were the least likely to be out of the closet; even controlling for their much lower social involvement, their expected score on openness was about .2 less than similar bisexual women and .5 to 6 lower than lesbians and gay men with similar characteristics. Lesbians paid the most attention to LGB policy issues; comparable gay men followed .27 behind; bisexual women followed another .11 behind; and bisexual men scored another .32 behind -.70 point lower than lesbians.

In addition, openness increased with age but decreased with education. Blacks, Latinos, and those of other/mixed race were significantly more out than comparable

\footnotetext{
${ }^{10}$ We may have the causal order backwards. One could plausibly argue that involvement in the LGB community increases one's probability of identifying as gay or lesbian rather than bisexual.
} 
whites. The non-religious and members of non-Judeo-Christian religions were more open than Protestants. Interest in LGB policy issues rose slightly with age and more strongly with both education and income. Blacks were less interested than comparable whites.

LGB activism rose with social involvement, openness, and interest in LGB rights (Model 5). Unsurprisingly, attention to LGB rights had the greatest impact (a one-point rise in attentiveness was associated with a .49-point rise in activism), but social involvement in the community was second-most important (a one-point rise was linked to a .37-point rise in activism, even holding attention to LGB rights constant; their respective beta-weights were .47 and .28). Being out had a small independent impact. Lesbians and gay men scored .4 higher on the LGB activism scale than bisexual women, however, even after controlling for their greater social involvement, policy interest, and openness. Bisexual men scored lower than bisexual women on interest, involvement, and openness but were more politically active when they scored equally.

How much impact did LGB socialization (social involvement in the gay/lesbian community, openness, and interest in LGB policy issues) have on liberalism, party identification, and Presidential vote? Table 4 repeats the logit models from Table 2, but for a sample restricted to LGBs and adding in the political socialization variables. Social involvement was the strongest predictor of ideology, with a one-point rise associated with a 17 percentage point increase in the probability of calling oneself liberal, holding the other variables at their means. In contrast, having "a lot" rather than "some" interest in LGB policy issues appeared to increase the probability of being liberal by only 8 
percentage points, though the two coefficients did not differ at the .05 significance level. Lesbians were 20 percentage points more likely than comparable gay men to be liberal, and openness about one's sexuality was not significantly related to ideology once these other variables were controlled. Consistent with general population patterns, Jewish and non-religious LGBs were more likely than Protestant LGBs to call themselves liberal (by 25 percentage points), and liberalism declined with age. In contrast to the general population, liberalism rose with income among LGBs.

In the Democratic party identification model, none of the sexual identity or LGB political socialization coefficients were individually significant. The three political socialization coefficients were also not jointly significant but, when they were dropped, gay men and lesbians were significantly more Democratic than comparable bisexuals. As in the general population, blacks and the non-religious were much more likely than others to be Democrats.

Attention to LGB rights had a strong impact on support for Gore, even with ideology and party identification in the model (its coefficient only drops from 0.81 to 0.71 when those variables are added). With all other variables held at their means, those who paid a lot of attention to hate crimes legislation, gay adoptions, gays in the military, legal recognition of same-sex unions, and laws prohibiting anti-gay workplace discrimination were 17 percentage points more likely to vote for Gore than those who paid no attention at all. In the second Gore Vote model in Table 3, the other political socialization and sexual identity variables were not individually or jointly significant, but they were strong predictors of attention to LGB issues. 
Without ideology and party identification in the model, blacks, Asians, and those of mixed/other race were more likely than comparable white LGBs to vote for Gore (all 24 blacks in the sample voted for him). Non-Christian and non-Jewish LGBs were substantially more likely than Protestant LGBs to vote for Gore. Party identification and ideology largely determined the Presidential vote, however; once they were included in the model, only Attention to LGB Rights and income retained a significant impact on whether LGBs voted for Gore.

\section{Conclusion}

LGB voters have supported the Democratic Presidential candidate at much higher rates than straight voters for at least the last six elections. Although Lewis and Rogers (2002) concluded that LGBs were no more likely than equally liberal heterosexuals of the same party to support the Democratic Presidential candidates in 1988 or 1996 , we find that lesbians and bisexuals were 20 percentage points, and gay men were 33 percentage points, more likely than comparable heterosexuals of the same sex to vote for Gore, even after controlling for ideology and party identification. Like Schaffner and Senic (2006), we conclude that LGB issues played a major role in Gore's very large LGB margin in 2000. Ideological and partisan differences between LGBs and heterosexuals explained one-fourth to one-third of the vote differences, but interest in LGB rights explained the rest.

Our study thus strengthens Schaffner and Senic's key finding that LGB issues were important in determining LGB votes. We confirm it on a much larger, more plausibly random sample, using a survey that includes a basic measure of ideology as 
well as sex, race/ethnicity, and age. Our conclusions about the relative importance of LGB issues and broader policy liberalism are weakened by the crudeness of the survey's measures of ideology and party identification and by the absence of questions on non-LGB policy issues, but LGB-specific issues clearly played a role in LGBs' voting in 2000. We suggest caution, however, in accepting Schaffner and Senic's conclusion that tangible economic benefits mattered more than more abstract rights. The five items on this survey addressed a wide array of issues (hate crimes laws, military service, nondiscrimination laws, recognition of same-sex relationships, and adoption rights) that are more rights than tangible economic benefits (though several have clear economic implications for some LGBs). Nonetheless, interest in these civil rights had a major impact. Further, despite the diversity of the items, they all loaded heavily on a single factor, casting doubt on whether LGBs distinguish between "tangible economic benefits" and "civil rights for the LGB community" as much as Schaffner and Senic (2006, p. 127) believe.

Our findings also support a model of political socialization within the LGB community. Lesbians and gay men are more liberal than are bisexuals. Gender, racial, religious, and educational differences partly account for the liberalism gap, but social involvement and interest in LGB rights increase liberalism, and bisexuals are less socially involved and care less about LGB rights. Controlling for these differences eliminates ideological differences between lesbians/gays and bisexuals. The apparent role of social involvement and interest in LGB rights in LGBs' liberalism also suggests that LGBs pick up cues from other LGBs in constructing a new political understanding of 
the world. Political socialization within the community seems necessary for LGBs to place such a high priority on LGB rights in their Presidential voting, but it also appears to play an important role in more general policy liberalism. Thus, embeddedness contributes to the conversion experience. Though Egan (2008) finds that neither the LGB composition of one's neighborhood nor age has much impact on LGBs' political distinctiveness, neither is a particularly strong measure of involvement in the LGB community. Our three-level subjective measure of social involvement in the gay and lesbian community also has its weaknesses, but it directly assesses LGBs' perceptions of their involvement with other LGBs.

LGBs are a theoretically interesting voting bloc, because their liberalism and party loyalty match those of groups with much longer histories with the Democratic Party and much stronger mechanisms for conveying their values to other members of the group (especially inter-generationally within the family). At least in the 2000 election, LGBs' perceptions of major differences between the parties on LGB rights appear to have played a major role in their Presidential vote. Unfortunately, data remain weak for testing whether LGB-specific interests have been as important in more recent elections. President Bush's support for a constitutional amendment to ban same-sex marriage certainly signaled LGB voters that the Republican Party did not value their interests, but LGBs also opposed the Iraq war earlier and more strongly than most Americans, which could also have led them to support Kerry and Obama. We need more surveys with sufficient random samples of LGBs to test how selfacceptance, community involvement, and attention to LGB leaders and peers affects 
broad policy liberalism, including on issues far removed from LGB rights, party identification, and Presidential voting. 


\section{References}

2000 Republican Platform. (2008). HistoryCentral.com: United States Presidential Elections. Retrieved from http://www.historycentral.com/elections/Conventions/RepPlat2000.html Bailey, R. W. (1999). Gay Politics, Urban Politics: Identity and Economics in the Urban Setting. New York: Columbia University Press.

Bailey, R. W. (2000). Out and Voting II: The Gay, Lesbian, and Bisexual Vote in Congressional Elections, 1990-98. New York: The Policy Institute of the National Gay and Lesbian Task Force.

Becker, H. S. (1963). Outsiders: Studies in the Sociology of Deviance. London: Free Press of Glencoe.

Berelson, B., Lazarsfeld, P. F., \& McPhee, W. N. (1986). Voting: A Study of Opinion Formation in a Presidential Campaign. Chicago: University of Chicago Press.

Campbell, A., Converse, P. E., Miller, W. E., \& Stokes, D. E. (1964). The American Voter. New York: John Wiley \& Sons.

Conover, P. J. (1984). The Influence of Group Identifications on Political Perception and Evaluation. The Journal of Politics, 46(3), 760-785.

Democratic Platform 2000. (2000). NewsHour with Jim Lehrer. Retrieved from http://www.pbs.org/newshour/bb/election/july-dec00/dem-platform3.html

Edelman, M. S. (1993). Understanding the Gay and Lesbian Vote in '92. The Public Perspective, 4(3), 32-33.

Egan, P. J. (2008). Explaining the Distinctiveness of Lesbians, Gays, and Bisexuals in 
American Politics. New York University.

Egan, P. J., Edelman, M. S., \& Sherrill, K. (2008). Findings from the Hunter College Poll: New Discoveries about the Political Attitudes of Lesbians, Gays and Bisexuals. Paper presented at the American Political Science Association. Gill Foundation. (2001). Out and Into the Voting Booth: Lesbian, Gay, Bisexual, and Transgender Voters in 2000. Denver: Gill Foundation.

Goffman, E. (1963). Stigma: Notes on the Management of Spoiled Identity. Englewood Cliffs: Prentice-Hall.

Green, D. P., Palmquist, B., \& Schickler, E. (2004). Partisan Hearts and Minds: Political Parties and the Social Identities of Voters: Yale University Press.

Greenstein, F. (1965). Children and Politics. New Haven: Yale University Press.

Herek, G. M., Norton, A. T., Allen, T. J., \& Sims, C. L. (2010). Demographic, Psychological, and Social Characteristics of Self-Identified Lesbian, Gay, and Bisexual Adults in a US Probability Sample. Sexuality Research and Social Policy, 1-25.

Hertzog, M. (1996). The Lavender Vote: Lesbians, Gay Men, and Bisexuals in American Electoral Politics. New York: NYU Press.

Jennings, M. K., \& Niemi, R. G. (1968). The Transmission of Political Values from Parent to Child. The American Political Science Review, 62(1), 169-184.

Laumann, E. O., Gagnon, J. H., Michael, R. T., \& Michaels, S. (1994). The Social Organization of Sexuality: Sexual Practices in the United States. Chicago: University of Chicago Press. 
Lewis, G. B., \& Edelson, J. L. (2000). DOMA and ENDA: Congress Votes on Gay Rights The Politics of Gay Rights (pp. 193-216).

Lewis, G. B., \& Rogers, M. A. (2002). Lesbian, Gay, and Bisexual Voters in Presidential Elections, 1988-2000. Paper presented at the American Political Science Association.

Lewis, G. B., Rogers, M. A., \& Sherrill, K. (2003). Sexual Identity, Sexual Behavior, and Group Socialization: Does Gay Sex Turn People into Liberal Democrats? Paper presented at the American Association for Public Opinion Research.

Pathela, P., Hajat, A., Schillinger, J., Blank, S., Sell, R., \& Mostashari, F. (2006).

Discordance between Sexual Behavior and Self-Reported Sexual Identity: A Population-Based Survey of New York City Men. Annals of Internal Medicine, 145(6), 416-425.

RFL Communications. (2000). Harris Interactive Uses Election 2000 to Prove Its Online MR Efficacy and Accuracy. Research Business Report, November, 1-2.

Schaffner, B., \& Senic, N. (2006). Rights or Benefits? Explaining the Sexual Identity Gap in American Political Behavior. Political Research Quarterly, 59(1), 123-132. Sherrill, K. (1996). The Political Power of Lesbians, Gays, and Bisexuals. PS: Political Science and Politics, 29(3), 469-473. 


$\begin{array}{crrrrrr}\text { Other } & 2.7 & 1.7 & 3.5 & 0.9 & 0.0 & 2.1 \\ \text { Sample size } & 5,613 & 523 & 198 & 6,394 & 172 & 233\end{array}$

${ }^{a}$ Figures are percentages of each identity who have this characteristic. 
Table 2. LGB Distinctiveness on Liberalism, Party Identification, and Vote

\begin{tabular}{|c|c|c|c|c|c|}
\hline Gay man & $\begin{array}{c}\frac{\text { Liberalism }}{1.72^{\star *}} \\
(8.02)\end{array}$ & $\begin{array}{c}\text { Democratic } \\
\text { Party ID } \\
1.20^{\star *} \\
(4.22)\end{array}$ & $\begin{array}{l}\begin{array}{c}\text { Gore } \\
\text { Vote I }\end{array} \\
2.01^{\star *} \\
(4.82)\end{array}$ & $\begin{array}{c}\text { Gore } \\
\text { Vote II } \\
1.39^{\star *} \\
(3.94)\end{array}$ & $\begin{array}{c}\begin{array}{c}\text { Gore } \\
\text { Vote III }\end{array} \\
0.12 \\
(0.18)\end{array}$ \\
\hline Lesbian & $\begin{array}{l}1.46^{* *} \\
(4.68)\end{array}$ & $\begin{array}{l}1.33^{* *} \\
(4.15)\end{array}$ & $\begin{array}{l}1.77^{\star *} \\
(3.66)\end{array}$ & $\begin{array}{c}0.90 \\
(1.33)\end{array}$ & $\begin{array}{c}-0.46 \\
(-0.54)\end{array}$ \\
\hline Bisexual male & $\begin{array}{l}0.74^{\star \star} \\
(3.21)\end{array}$ & $\begin{array}{c}0.08 \\
(0.14)\end{array}$ & $\begin{array}{l}1.24^{\star \star} \\
(4.47)\end{array}$ & $\begin{array}{l}0.94^{* *} \\
(2.80)\end{array}$ & $\begin{array}{c}-0.01 \\
(-0.02)\end{array}$ \\
\hline Bisexual female & $\begin{array}{c}0.08 \\
(0.15)\end{array}$ & $\begin{array}{c}0.27 \\
(1.25)\end{array}$ & $\begin{array}{c}0.80^{*} \\
(2.49)\end{array}$ & $\begin{array}{c}0.94^{*} \\
(2.16)\end{array}$ & $\begin{array}{c}-0.09 \\
(-0.15)\end{array}$ \\
\hline Male & $\begin{array}{l}-0.61^{* *} \\
(-6.12)\end{array}$ & $\begin{array}{l}-0.49^{* *} \\
(-5.81)\end{array}$ & $\begin{array}{l}-0.80^{\star *} \\
(-7.03)\end{array}$ & $\begin{array}{l}-0.50^{* *} \\
(-3.45)\end{array}$ & $\begin{array}{l}-0.50^{* *} \\
(-3.45)\end{array}$ \\
\hline $\begin{array}{l}\text { Attention to LGB } \\
\text { policy issues }\end{array}$ & . & & & & $\begin{array}{c}0.57^{*} \\
(2.40)\end{array}$ \\
\hline Liberal & . & . & . & $\begin{array}{l}1.22^{\star \star} \\
(5.76)\end{array}$ & $\begin{array}{l}1.22^{\star \star} \\
(5.74)\end{array}$ \\
\hline Conservative & . & . & . & $\begin{array}{l}-1.58^{\star *} \\
(-8.67)\end{array}$ & $\begin{array}{l}-1.58^{* *} \\
(-8.67)\end{array}$ \\
\hline Democrat & . & . & . & $\begin{array}{c}2.05^{\star \star} \\
(12.98)\end{array}$ & $\begin{array}{c}2.05^{\star \star} \\
(12.98)\end{array}$ \\
\hline Republican & . & & & $\begin{array}{c}-2.12^{\star *} \\
(-11.64)\end{array}$ & $\begin{array}{c}-2.10^{* *} \\
(-11.65)\end{array}$ \\
\hline African American & $\begin{array}{c}0.48^{*} \\
(2.16)\end{array}$ & $\begin{array}{c}2.66^{\star \star} \\
(11.55)\end{array}$ & $\begin{array}{l}2.46^{\star *} \\
(5.87)\end{array}$ & $\begin{array}{c}1.09^{*} \\
(2.54)\end{array}$ & $\begin{array}{l}1.11^{\star *} \\
(2.58)\end{array}$ \\
\hline Latino & $\begin{array}{c}0.02 \\
(0.07)\end{array}$ & $\begin{array}{c}0.34 \\
(1.48)\end{array}$ & $\begin{array}{c}0.35 \\
(1.26)\end{array}$ & $\begin{array}{c}0.27 \\
(0.80)\end{array}$ & $\begin{array}{c}0.27 \\
(0.79)\end{array}$ \\
\hline Asian American & $0.59^{* *}$ & 0.48 & 0.61 & 0.07 & 0.07 \\
\hline
\end{tabular}




\begin{tabular}{|c|c|c|c|c|c|}
\hline & $(2.66)$ & $(1.40)$ & $(1.09)$ & $(0.08)$ & $(0.09)$ \\
\hline Other/Mixed & $\begin{array}{l}0.49^{* *} \\
(2.84)\end{array}$ & $\begin{array}{l}0.38^{\star *} \\
(2.70)\end{array}$ & $\begin{array}{l}0.23 \\
(1.05)\end{array}$ & $\begin{array}{l}-0.13 \\
(-0.40)\end{array}$ & $\begin{array}{l}-0.12 \\
(-0.38)\end{array}$ \\
\hline Age & $\begin{array}{l}-0.04 \\
(-1.95)\end{array}$ & $\begin{array}{c}0.01 \\
(0.48)\end{array}$ & $\begin{array}{l}-0.02 \\
(-0.62)\end{array}$ & $\begin{array}{c}-0.03 \\
(-0.95)\end{array}$ & $\begin{array}{c}-0.04 \\
(-1.01)\end{array}$ \\
\hline Age (years-square & $\begin{array}{l}\text { d) } 0.00 \\
(1.68)\end{array}$ & $\begin{array}{l}-0.00 \\
(-0.12)\end{array}$ & $\begin{array}{l}0.00 \\
(0.78)\end{array}$ & $\begin{array}{l}0.00 \\
(1.05)\end{array}$ & $\begin{array}{c}0.00 \\
(1.11)\end{array}$ \\
\hline Education (years) & $\begin{array}{l}-0.20 \\
(-1.36)\end{array}$ & $\begin{array}{l}-0.71^{\star *} \\
(-4.51)\end{array}$ & $\begin{array}{l}-0.63^{\star *} \\
(-3.72)\end{array}$ & $\begin{array}{l}-0.34 \\
(-1.44)\end{array}$ & $\begin{array}{l}-0.34 \\
(-1.40)\end{array}$ \\
\hline $\begin{array}{l}\text { Education } \\
\text { (years-squared) }\end{array}$ & $\begin{array}{c}0.01 \\
(1.80)\end{array}$ & $\begin{array}{l}0.02^{* *} \\
(4.61)\end{array}$ & $\begin{array}{l}0.02^{\star *} \\
(4.07)\end{array}$ & $\begin{array}{c}0.01 \\
(1.71)\end{array}$ & $\begin{array}{c}0.01 \\
(1.66)\end{array}$ \\
\hline $\begin{array}{l}\text { Household income } \\
(\$ 100,000 \mathrm{~s})\end{array}$ & $\begin{array}{c}0.01 \\
(0.06)\end{array}$ & $\begin{array}{l}-0.33^{\star *} \\
(-3.56)\end{array}$ & $\begin{array}{l}-0.35^{\star \star} \\
(-2.67)\end{array}$ & $\begin{array}{l}-0.21 \\
(-1.17)\end{array}$ & $\begin{array}{l}-0.22 \\
(-1.22)\end{array}$ \\
\hline Catholic & $\begin{array}{l}0.44^{\star *} \\
(4.15)\end{array}$ & $\begin{array}{l}0.41^{\star \star} \\
(3.58)\end{array}$ & $\begin{array}{c}0.26 \\
(1.88)\end{array}$ & $\begin{array}{l}-0.14 \\
(-0.73)\end{array}$ & $\begin{array}{c}-0.12 \\
(-0.66)\end{array}$ \\
\hline Jewish & $\begin{array}{l}1.29^{\star \star} \\
(4.84)\end{array}$ & $\begin{array}{l}1.74^{\star \star} \\
(8.75)\end{array}$ & $\begin{array}{l}2.42^{* *} \\
(9.68)\end{array}$ & $\begin{array}{l}1.74^{\star \star} \\
(4.23)\end{array}$ & $\begin{array}{l}1.73^{\star \star} \\
(4.20)\end{array}$ \\
\hline Other religion & $\begin{array}{l}0.36 \\
(1.79)\end{array}$ & $\begin{array}{l}0.60^{\star *} \\
(4.41)\end{array}$ & $\begin{array}{c}0.11 \\
(0.32)\end{array}$ & $\begin{array}{l}-0.50 \\
(-1.31)\end{array}$ & $\begin{array}{l}-0.51 \\
(-1.33)\end{array}$ \\
\hline No religion & $\begin{array}{c}1.34^{* *} \\
(10.52)\end{array}$ & $\begin{array}{l}0.79^{* *} \\
(7.14)\end{array}$ & $\begin{array}{l}1.12^{* *} \\
(8.53)\end{array}$ & $\begin{array}{l}0.48^{\star \star} \\
(2.68)\end{array}$ & $\begin{array}{l}0.48^{\star \star} \\
(2.67)\end{array}$ \\
\hline Observations 11,6 & 648 & 11,381 & 10,118 & 10,118 & 10,118 \\
\hline
\end{tabular}


Table 3. Identity, Community, Openness, Interest in LGB Policy Issues, and LGB Activism

\section{Gay/Lesbian Social Openness onAttention to LGB}

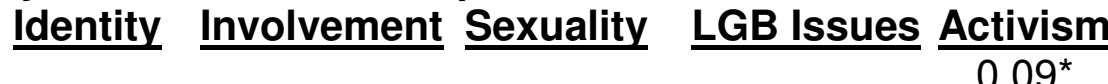

Openness about sexuality

Attention to LGB $0.49^{* *}$ policy issues $(21.40)$ Social involvement in
LGB community $0.27^{\star *}$ (11.19)

$$
\begin{array}{cc}
0.45^{\star *} & 0.37^{\star *} \\
(11.83) & (12.20)
\end{array}
$$

Gay man

$3.05^{\star *}$

$0.60^{\star *}$

$0.22^{\star *}$

(7.18)

(13.72)

Lesbian

$1.43^{* *}$

$0.33^{\text {** }}$

$0.43^{\star *}$

(6.16)

(5.87)

$0.38^{* *}$

$0.41^{\text {** }}$

(3.23)

(4.28)

(6.19)

Male

$1.28^{* *}$

$-1.35^{* *}$

$-0.20^{* *}$

$-0.32^{* *}$

$0.22^{\star *}$

(4.78)

$(-3.25)$

$(-4.53)$

(4.25)

African American

$-1.13^{*}$

$-0.62$

$0.14^{\text {** }}$

$(-4.64)$

(3.09)

$-0.17^{*}$

$-0.41^{\text {** }}$

$(-1.99)$

$(-1.04)$

$(-2.33)$

$(-7.77)$

Latino

$$
\begin{gathered}
0.64 \\
(1.32)
\end{gathered}
$$

0.66

$0.11^{*}$

0.02

$0.14^{\star *}$

(2.51)

(0.30)

(2.86)

Asian American

$\begin{array}{cc}-0.19 & -0.62 \\ (-0.34) & (-0.95)\end{array}$

0.03

(0.19)

0.01

$-0.17$

$(-0.34)$

Other/Mixed

$$
\begin{gathered}
0.03 \\
(0.07)
\end{gathered}
$$

$1.09^{* *}$

$0.24^{\star *}$

(3.31)

(0.04)

$(-0.83)$

(2.60)

$-0.12$

0.11

$(-1.03)$

Catholic

$$
\begin{gathered}
0.07 \\
(0.18)
\end{gathered}
$$

0.47

0.07

$-0.03$

0.07

(1.24)

(1.67)

$(-0.43)$

(1.35)

Jewish

-0.14
$(-0.27)$

0.78
$(1.26)$

0.08

(0.53)

0.28

$-0.06$

$(-0.34)$ 


$\begin{array}{lccccc}\text { Other religion } & -0.33 & -0.34 & 0.20^{* *} & 0.12 & 0.05 \\ & (-1.00) & (-0.97) & (4.83) & (1.83) & (0.98) \\ & & & & & \\ \text { No religion } & 0.67^{*} & 0.43 & 0.09^{*} & 0.09 & 0.03 \\ & (2.03) & (1.48) & (2.28) & (1.51) & (0.60) \\ & & & & & \\ \text { Age (years) } & 0.02 & -0.03^{* *} & 0.01^{* *} & 0.00^{* *} & -0.01^{* *} \\ & (1.64) & (-2.82) & (4.82) & (2.62) & (-4.81) \\ \text { Education (years) } & 0.12^{*} & -0.03 & -0.03^{* *} & 0.06^{* *} & -0.01 \\ & (2.20) & (-0.67) & (-5.64) & (6.22) & (-1.68) \\ \text { Household income } & 0.31 & 0.27 & 0.05 & 0.15^{\star *} & -0.10^{* *} \\ \quad \text { (\$100,000s) } & (1.09) & (1.35) & (1.70) & (3.10) & (-2.94) \\ & & & & & \\ \text { Observations } & 1,053 & 1,053 & 1,053 & 1,053 & 1,053 \\ \text { R-squared } & & & 0.448 & 0.371 & 0.695\end{array}$

Robust z-statistics in parentheses ${ }^{* *} p<0.01,{ }^{*} p<0.05$ 
Table 4. Liberalism, Party Identification, and Vote among LGBs

\begin{tabular}{|c|c|c|c|c|}
\hline Interest in LGB issues & $\begin{array}{c}\text { Liberalism } \\
0.33^{*} \\
(2.05)\end{array}$ & $\begin{array}{c}\text { Democratic } \\
\text { Party ID } \\
0.32 \\
(1.46)\end{array}$ & $\begin{array}{c}\begin{array}{c}\text { Gore } \\
\text { Vote A }\end{array} \\
0.81^{* *} \\
(3.23)\end{array}$ & $\begin{array}{c}\begin{array}{c}\text { Gore } \\
\text { Vote B }\end{array} \\
0.71^{\star *} \\
(2.87)\end{array}$ \\
\hline Social involvement & $\begin{array}{l}0.72^{\star *} \\
(3.28)\end{array}$ & $\begin{array}{l}-0.04 \\
(-0.17)\end{array}$ & $\begin{array}{l}-0.17 \\
(-0.59)\end{array}$ & $\begin{array}{l}-0.23 \\
(-0.79)\end{array}$ \\
\hline Openness on sexuality & $\begin{array}{l}-0.04 \\
(-0.14)\end{array}$ & $\begin{array}{l}0.18 \\
(0.67)\end{array}$ & $\begin{array}{l}0.32 \\
(0.94)\end{array}$ & $\begin{array}{l}0.24 \\
(0.64)\end{array}$ \\
\hline Gay man & $\begin{array}{l}-0.25 \\
(-0.61)\end{array}$ & $\begin{array}{c}0.40 \\
(1.03)\end{array}$ & $\begin{array}{c}0.45 \\
(0.94)\end{array}$ & $\begin{array}{c}0.94 \\
(1.93)\end{array}$ \\
\hline Lesbian & $\begin{array}{l}1.48^{\star *} \\
(2.82)\end{array}$ & $\begin{array}{c}0.67 \\
(1.47)\end{array}$ & $\begin{array}{c}0.27 \\
(0.40)\end{array}$ & $\begin{array}{c}-0.15 \\
(-0.14)\end{array}$ \\
\hline Male & $\begin{array}{c}0.91 \\
(1.76)\end{array}$ & $\begin{array}{l}-0.30 \\
(-0.74)\end{array}$ & $\begin{array}{l}-0.27 \\
(-0.52)\end{array}$ & $\begin{array}{l}-0.30 \\
(-0.58)\end{array}$ \\
\hline Liberal & . & . & . & $\begin{array}{r}0.97^{*} \\
(2.35)\end{array}$ \\
\hline Conservative & . & . & . & $\begin{array}{l}-0.48 \\
(-0.88)\end{array}$ \\
\hline Democrat & . & . & . & $\begin{array}{l}3.25^{\star \star} \\
(5.44)\end{array}$ \\
\hline Republican & . & . & . & $\begin{array}{l}-2.87^{\star *} \\
(-6.11)\end{array}$ \\
\hline African American & $\begin{array}{l}-0.96 \\
(-1.64)\end{array}$ & $\begin{array}{l}2.11^{* *} \\
(3.45)\end{array}$ & $A$ & A \\
\hline Latino & $\begin{array}{l}-0.69 \\
(-1.64)\end{array}$ & $\begin{array}{l}-0.26 \\
(-0.56)\end{array}$ & $\begin{array}{l}-0.50 \\
(-0.95)\end{array}$ & $\begin{array}{l}-0.45 \\
(-0.75)\end{array}$ \\
\hline Asian American & $\begin{array}{c}-0.27 \\
(-0.22)\end{array}$ & $\begin{array}{c}1.43 \\
(1.70)\end{array}$ & $\begin{array}{c}1.76 \\
(1.54)\end{array}$ & $\begin{array}{c}-0.39 \\
(-0.36)\end{array}$ \\
\hline
\end{tabular}




\begin{tabular}{|c|c|c|c|c|}
\hline Other/Mixed & $\begin{array}{c}0.66 \\
(1.20)\end{array}$ & $\begin{array}{l}1.03^{*} \\
(2.38)\end{array}$ & $\begin{array}{l}1.80^{*} \\
(2.12)\end{array}$ & $\begin{array}{c}0.50 \\
(0.78)\end{array}$ \\
\hline Catholic & $\begin{array}{c}0.12 \\
(0.38)\end{array}$ & $\begin{array}{c}0.30 \\
(0.64)\end{array}$ & $\begin{array}{c}-0.04 \\
(-0.08)\end{array}$ & $\begin{array}{c}-0.07 \\
(-0.16)\end{array}$ \\
\hline Jewish & $\begin{array}{c}1.10 \\
(1.23)\end{array}$ & $\begin{array}{c}0.52 \\
(0.74)\end{array}$ & $\begin{array}{c}0.04 \\
(0.06)\end{array}$ & $\begin{array}{c}0.25 \\
(0.39)\end{array}$ \\
\hline Other religion & $\begin{array}{l}-0.02 \\
(-0.04)\end{array}$ & $\begin{array}{c}0.68 \\
(1.83)\end{array}$ & $\begin{array}{l}1.10^{*} \\
(2.26)\end{array}$ & $\begin{array}{c}1.10 \\
(1.72)\end{array}$ \\
\hline No religious affiliation & $\begin{array}{l}1.07^{\star *} \\
(3.80)\end{array}$ & $\begin{array}{l}1.01^{\star *} \\
(2.88)\end{array}$ & $\begin{array}{l}1.32^{\star \star} \\
(2.97)\end{array}$ & $\begin{array}{c}0.46 \\
(0.84)\end{array}$ \\
\hline Age & $\begin{array}{l}-0.03^{* *} \\
(-2.78)\end{array}$ & $\begin{array}{c}0.02 \\
(1.33)\end{array}$ & $\begin{array}{c}0.02 \\
(1.25)\end{array}$ & $\begin{array}{c}0.02 \\
(1.38)\end{array}$ \\
\hline Education (years) & $\begin{array}{c}0.01 \\
(0.26)\end{array}$ & $\begin{array}{c}-0.03 \\
(-0.49)\end{array}$ & $\begin{array}{c}0.04 \\
(0.53)\end{array}$ & $\begin{array}{c}0.04 \\
(0.54)\end{array}$ \\
\hline Household income & $\begin{array}{l}0.73^{\star *} \\
(2.71)\end{array}$ & $\begin{array}{c}0.46 \\
(1.47)\end{array}$ & $\begin{array}{c}-0.35 \\
(-1.06)\end{array}$ & $\begin{array}{l}-1.00^{* *} \\
(-2.62)\end{array}$ \\
\hline Observations & 997 & 961 & 839 & 839 \\
\hline \multicolumn{5}{|c|}{ Robust z-statistics in parentheses ${ }^{* *} p<0.01,{ }^{*} p<0.05$} \\
\hline
\end{tabular}

